\title{
Beyond Matrices and Black-box Algorithms: Setting Marketing Priorities with Marketing Strategy Conferences
}

\author{
Martin S Schilling ${ }^{1}$ and Paul J Schulze-Cleven ${ }^{2}$
}

\footnotetext{
${ }^{1}$ London School of Economics, Management Department, London School of Economics, Decision Institute Berlin (m.schilling@lse.ac.uk)

${ }^{2}$ Decision Institute Berlin, Charlottenstrasse 159, 10117 Berlin (p.schulzecleven@decisioninstitute.eu)
} 
First published in Great Britain in 2007

by the Operational Research Group, Department of Management London School of Economics and Political Science

\section{Copyright (C) The London School of Economics and Political Science, 2007}

The contributors have asserted their moral rights.

All rights reserved. No part of this publication may be reproduced, stored in a retrieval system, or transmitted in any form or by any means, without the prior permission in writing of the publisher, nor be circulated in any form of binding or cover other than that in which it is published.

Typeset, printed and bound by:

The London School of Economics and Political Science

Houghton Street

London WC2A 2AE

Working Paper No: LSEOR 07.100

ISBN: 978-0-85328-056-9 


\section{Beyond Matrices and Black-box Algorithms: Setting Marketing Priorities with Marketing Strategy Conferences}

Schilling, Martin S.

London School of Economics

Management Department, London School of Economics,

Houghton Street, London, WC2A 2AE, UK

Decision Institute Berlin

(m.schilling@Ise.ac.uk)

Schulze-Cleven, Paul J.

Decision Institute Berlin

Charlottenstrasse 159, 10117 Berlin

(p.schulzecleven@decisioninstitute.eu)

Keywords: resource allocation, prioritisation, capital planning, marketing mix, decision conference, multiple-attribute utility theory, Marketing Strategy Conferences

\section{Summary}

With this paper, we introduce the Marketing Strategy Conference approach to set strategic marketing priorities effectively and allocate marketing-related resources accordingly. The system is based on managerial preference modelling with a decision model (analytical side) and communication-enhancing strategy conferencing (interactive side). After a review of alternative resource allocation frameworks, as over-the-thumb approaches, matrix-based analyses, statistical analyses or management science models, we analyse existing analytical, behavioural and organisational impediments to effective marketing resource allocation. Addressing some of this impediments, this papers outlines two Marketing Strategy Conference cases, which we carried out for the pharmaceutical, Schering Argentina. 


\section{Introduction}

"Formal systems, mechanical or otherwise, have offered no improved means of dealing with the information overload of human brains ... All the promises about artificial intelligence, expert systems, and the like improving if not replacing human intuition never materialized at the strategy level. Formal system could certainly process more information, at least hard information. But they could never internalize it, comprehend it, synthesize it." - Mintzberg, 1994 (p.111)

The idea of supporting strategic marketing decisions with computer-based models goes back at least to the middle of the 1960's (Kuehn, 1965; Little and Lodish, 1969a; Montgomery and Urban, 1969). The core idea is to combine the adaptable, but sometimes biased judgements of marketeers with the consistent, but sometimes rigid data processing capabilities of formal models ( $\mathrm{Li}, 2005)$. Models include amongst others, Artificial Neural Networks (Poh, 1994; Chien, 1999), fuzzy logic (Levy and Yoon, 1995; Kuo and Xue, 1998), expert information systems (McDonald and Wilson, 1990; Alpar, 1991) and case-based approaches (Chiu, 2002; Changchiena and Lin, 2005). Li et al (2000) provides a review of these approaches.

Reflecting Mintzberg's quote above, the results for effective applications of model-based support in marketing decision making, however, are mixed. The application of formal systems is usually limited to a narrow domain. Ill-defined decision problems with multiple objectives in the face of uncertainty, common in practice, are difficult to capture in a simple computer model. Consequently, a survey with marketing managers of manufacturing companies in the UK indicate widespread dissatisfaction with computer-based systems used in developing marketing strategies (Li et al., 2000). In particular, most systems fail to aid strategic thinking and to couple strategic analysis with managerial judgments. 
To address this dissatisfaction, this paper aims to introduce a system - Marketing Strategy Conferencing (MSC) - with an analytical and an interactive component to aid marketing managers set strategic marketing priorities effectively and allocate resources accordingly. Analytically, MSC builds on recent advances in the area of decision analysis in order to provide marketeers with insights in efficient trade-offs between strategic marketing initiatives. We are looking in particular at investments in different marketing programs (direct customer service activities, loyalty programs, direct advertising, etc.) or trade-offs between marketing activities for different product groups. Besides this analytical component, the system is interactive by providing organisations with a discussion framework to create strategic consensus, i.e. shared understanding on marketing priorities (Rapert et al., 2002). The system is designed to combine the operational bottom-up knowledge of marketing managers with the strategic vision of top-level management. The aim of the interactive component of the system is thereby to contribute to bridging the gap between marketing strategy formulation and implementation (Bonoma, 1984; Bonoma and Crittenden, 1988; Cespedes and Piercy, 1996; Lane and Clewes, 2000).

The rest of the paper is structured as follows: in the next section, we outline some existing methodologies to analyse strategic marketing prioritisations and to allocate resources accordingly. We then highlight analytical, behavioural and organisational impediments which hinder effective priority setting in marketing. Addressing some of these impediments we, thirdly, introduce the Marketing Strategy Conferencing approach, applied to two cases in the pharmaceutical, Schering Argentina. 


\section{Resources Allocation Methodologies For Marketing-related Decisions}

Frameworks to set marketing priorities and to allocate resources are numerous. As displayed in Table 1, at least four classes of these methods exist:

- 'over-the-thumb' approaches (resource allocation heuristics), such as the percentage-ofsales method (Piercy, 1986; Lilien and Rangaswamy, 2003; Dibb et al., 2006; Kotler and Keller, 2006),

- matrix-based strategic approaches, including the BCG growth/share matrix or the directional policy matrix (Henderson, 1979; Wind and Mahajan, 1981; Morrison and Wensley, 1991; Baker, 2000)

- statistical analyses, mostly based on complex regression models (Blattberg and Deighton, 1996; Thomas et al., 2004; Reinartz et al., 2005)

- decision modelling approaches, including linear programming models, the Analytical Hierarchy Process or Multiple-Criteria Decision Analysis (Kuehn, 1965; Little, 1976; Davies, 1994; Richardson, 2004; Phillips and Bana e Costa, 2006).

\section{‘Over-the-thumb’ Approaches (Resource Allocation Heuristics)}

In particular when setting advertising budgets, various simple 'over-the-thumb' methods to allocate resources exist. Methods range from allocating budgets according to what managers consider their company can afford (Piercy, 1986; Piercy, 2002), to setting marketing objectives and allocating budgets to achieve these targets (Piercy, 1986; Dibb et al., 2006). Other common approaches include spending a fixed percentage of (current or forecasted) sales or to match the marketing expenditures of competitors or an industry (Piercy, 2002). Although 'over-the-thumb' approaches can be applied in a time saving manner, they are based on arbitrary assumptions, such as that sales creates advertising, rather than vice versa or they ignore the fact that competitors might have completely different 
marketing objectives (Dibb et al., 2006; Piercy, 1986; Lilien and Little, 1976; Dalrymple and Thorelli, 1984).

\section{Matrix-based Strategic Approaches}

To provide a more structured framework for strategic marketing decisions, The Boston Consulting Group introduced the growth-share matrix in the 1970's (Henderson, 1979). As market growth is only a rough proxy for market attractiveness and as market share only partially captures competitiveness, more-dimensional approaches have won wider acceptance in the last few decades. Shell's Directional Policy Matrix or the business profile matrix, for example, offer a multiple factor framework to analyse portfolios (for a review of matrix-based approaches see Wind and Mahajan, 1981). Matrix-based portfolio analyses usually aim to classify and compare a firm's products or services in order to analyse optimal investment strategies for each product or service. In most cases, one axis represents internal factors such as the competitiveness of the firm's products, and the other, external factors, such as market opportunities (Day, 1977; Wensley, 1981; Brown, 1991; Morrison and Wensley, 1991; Dibb et al., 2006).

Despite their wide applicability in practice, matrix-based portfolio analyses have been criticised for being too generic to provide a sound basis for marketing strategy development (Wensley, 1981). With the BCG matrix, for example, decision makers do not obtain guidance on which 'problem child' to invest in or how many 'cash cows' to maintain. In addition to this over-simplification issue, the definition of categories, cut-off points and markets, influence the results of matrix-based portfolio analyses significantly. Matrix-based portfolio approaches can therefore be misleading when allocating budgets or developing strategies (Day, 1977). Another criticism of matrix-based approaches focuses on the underlying 'classical' productlife-cycle, which has been criticised for not being universally applicable (Dhalla, 1976). 


\section{Statistical Analyses}

A more recent development is statistical analyses, which aim to provide guidance for an efficient allocation of marketing-mix related resources. These approaches are usually based on complex regression models to determine how much and where to spend marketing resources. Thomas et al. (2004), for example, introduced the Allocating Resources for Profits (APRO) approach, which aims to determine optimal investments by balancing spending between retaining old and attracting new customers. As one of the earlier statistical approaches, Blattberg and Deighton (1996) chose customer equity as resource allocation criterion for maximising the firm's long-term profitability. Using more advanced statistical models Venkatesan and Kumar (2004) as well as Rust et al. (2004) analyse strategic marketing initiatives based on their discounted customer life time value. In comparison to the other approaches, statistical analyses offer precise calculations on how much to spend in different marketing expenditures. On the other hand, the complex calculations and the lack of interactive models to discuss strategic issues are the potential drawbacks of these approaches.

\section{Decision Modelling Approaches}

Researchers have been developing decision models since the 1960's to aid marketing strategy development as well as the allocation of marketing resources (see for example, Kuehn, 1965; Montgomery and Urban, 1969; Little and Lodish, 1969b; Lodish, 1971; Vargas and Saaty, 1981; Nguyen, 1985; Mazanec, 1986; Eliashberg et al., 2002; Richardson, 2004). Linear programming models, the Analytical Hierarchy Process and multiple criteria decision models have so far been the most prevalent management science approaches to marketingrelated decisions. 
Linear programming models use an optimisation function (such as maximising sales) and constraints (such as a budget) to calculate optimal resource allocations (Hillier and Lieberman, 2005). Due to the complexity and lack of adaptiveness of early linear programming models, Little (1976) introduced more simple marketing science models. Following his 'Decision Calculus' school, researchers developed software based tools to help marketing managers allocate resources and develop marketing strategies. MEDIAC, for example, deals with selecting media options to create a media schedule (Little and Lodish, 1969a). CALLPLAN guides a salesperson in optimally allocating their time with customers (Lodish, 1971). SPRINTER allocates effort to marketing activities for the launch of a new product (Urban, 1970). Lodish, Curtis et al. (1988), used a custom model to analyse the optimal sales force size and how an organisation should deploy it. For a brief review of these approaches, see Richardson (2004). Linear programming models have been applied successfully in practice, nonetheless it remains challenging to build models which are sufficiently complex to capture the whole picture of a decision situation and, at the same time, remain sufficiently simple to be usable (Lodish, 2001).

Whereas linear programming approaches usually optimise a single criterion, such as profit or sales, the Analytical Hierarchy Process (Saaty, 1977, 1980) is able to deal with marketing-related trade-off problems. The Analytical Hierarchy Process (AHP) serves to structure portfolio decisions in hierarchical representations including different options and different objectives for the evaluation of the options (Davies, 1994). The AHP was used to aid in lease versus buy decisions in industrial purchasing (Vargas and Saaty, 1981), new product screening (Calantone et al., 1999), marketing mix strategy, new product development (Wind and Saaty, 1980), and advertising budget optimisation (Mazanec, 1986). Although the process simplifies cognitive demands on the decision makers by using pairwise comparisons of options (Davies, 2001), researchers have challenged the theoretical soundness of the 
Analytical Hierarchy Process. According to Dyer (1990), for example, the AHP can lead to arbitrary, rather than systematic rankings of decision alternatives.

Finally, models based on multiple attribute utility theory (Keeney and Raiffa, 1976) can capture trade-offs between conflicting objectives in a theoretically consistent way. These conflicting objectives might include growth of market share, short-term profitability, image effects or the reduction of risk. Using this approach, Phillips and Bana e Cost (2006) combine simple preference modelling with communication-enhancing decision conferencing (Phillips, 2006) for an efficient allocation of resources and strategic group alignment. They are therefore in particular suitable for the Marketing Strategy Conferencing approach, as introduced below. Major drawbacks of multiple criteria models include difficult judgments on the part of the decision makers, in particular when weighting dimensions.

Table 1 gives an overview of the four approaches to allocate resources in marketingrelated decisions, as discussed above. 


\begin{tabular}{|c|c|c|c|c|}
\hline \multicolumn{5}{|c|}{ Resource Allocation Frameworks for Marketing Decisions } \\
\hline & Core Concept & Examples & Major Advantages & Major Drawbacks \\
\hline $\begin{array}{l}\text { 'Over-the-thumb' } \\
\text { Approaches } \\
\text { (Heuristics) }\end{array}$ & $\begin{array}{l}\text { Simple approaches without } \\
\text { extensive quantitative } \\
\text { analyses }\end{array}$ & $\begin{array}{l}\text { - Affordability approach } \\
\text { - Objective and task method } \\
\text { - Percentage-of-sales approach } \\
\text { - Competition matching approach } \\
\text { (see Lilien and Little, 1976; } \\
\text { Dalrymple and Thorelli, 1984; } \\
\text { Piercy, 1986; Lilien and } \\
\text { Rangaswamy, 2003; Dibb et al., } \\
\text { 2006) }\end{array}$ & $\begin{array}{l}\text { Time saving 'just-enough' } \\
\text { approaches }\end{array}$ & $\begin{array}{l}\text { - Approaches are partly } \\
\text { arbitrary } \\
\text { - Approaches rely on false } \\
\text { assumptions }\end{array}$ \\
\hline $\begin{array}{l}\text { Matrix-based } \\
\text { Strategic } \\
\text { Approaches }\end{array}$ & $\begin{array}{l}\text { Simultaneous analysis of } \\
\text { several resource allocation } \\
\text { options, usually related to } \\
\text { market attractiveness } \\
\text { (external) and competitive } \\
\text { capabilities (internal) }\end{array}$ & $\begin{array}{l}\text { - BCG Growth/Share Matrix } \\
\text { (Henderson, 1979) } \\
\text { - Directional Policy Matrix } \\
\text { (Shell, 1975) } \\
\text { - Business Profile Matrix } \\
\text { (Wright, 1978) }\end{array}$ & $\begin{array}{l}\text { High-level overview of the } \\
\text { strategic positioning of different } \\
\text { products/SBU, etc. }\end{array}$ & $\begin{array}{l}\text { - Oversimplification } \\
\text { - Very generic insights } \\
\text { into efficient allocation of } \\
\text { resources } \\
\text { - Problems with definitions of } \\
\text { categories, cut-off points } \\
\text { and weights of dimensions }\end{array}$ \\
\hline $\begin{array}{l}\text { Statistical } \\
\text { Analyses }\end{array}$ & $\begin{array}{l}\text { Analysis of marketing-mix } \\
\text { related resources based on } \\
\text { complex statistical modelling } \\
\text { (usually regression analyses) }\end{array}$ & $\begin{array}{l}\text { - Allocating Resources for Profits - } \\
\text { APRO (Thomas et al., 2004) } \\
\text { - Maximising customer equity, i.e. } \\
\text { customer life time value as } \\
\text { resource allocation criterion } \\
\text { (Blattberg and Deighton, 1996, } \\
\text { Rust et al., 2004; Venkatesan } \\
\text { and Klumar, 2004) }\end{array}$ & $\begin{array}{l}\text { Precise calculations on how much } \\
\text { and where to spend marketing } \\
\text { resources }\end{array}$ & $\begin{array}{l}\text { - Complicated algebra } \\
\text { ('black-box' problems) } \\
\text { - Lack of interactive } \\
\text { component to create } \\
\text { strategic consensus and } \\
\text { commitment to } \\
\text { implementation }\end{array}$ \\
\hline \multirow{3}{*}{$\begin{array}{l}\text { Decision } \\
\text { Modelling } \\
\text { Approaches }\end{array}$} & \multirow{3}{*}{$\begin{array}{l}\text { Decision models with a special } \\
\text { emphasis on including } \\
\text { managerial judgments to } \\
\text { allocate marketing resource } \\
\text { efficiently }\end{array}$} & $\begin{array}{l}\text { - Linear Programming } \\
\text { Models (reviewed by } \\
\text { Richardson, 2004) }\end{array}$ & $\begin{array}{l}\text { Precise recommendations on how } \\
\text { to spend resources, in particular } \\
\text { when only monetary dimensions } \\
\text { matter }\end{array}$ & $\begin{array}{l}\text { - Models can be complicated } \\
\text { to understand ('Black-box' } \\
\text { problem) }\end{array}$ \\
\hline & & $\begin{array}{l}\text { - Analytical Hierarchy Process } \\
\text { (Saaty, 1977, 1980) }\end{array}$ & $\begin{array}{l}\text { Pair-wise comparisons facilitate } \\
\text { easy managerial judgements }\end{array}$ & $\begin{array}{l}\text { - Approach can lead to } \\
\text { inconsistent results (Dyer, } \\
\text { 1990) }\end{array}$ \\
\hline & & $\begin{array}{l}\text { - Multiple-Criteria Decision } \\
\text { Analysis (Keeney and } \\
\text { Raiffa, 1976; Phillips and } \\
\text { Bana e Costa, 2006) }\end{array}$ & $\begin{array}{l}\text { Consistent integration of financial } \\
\text { and non-financial objectives; } \\
\text { emphasis on strategic consensus } \\
\text { finding through visual group } \\
\text { decision support }\end{array}$ & $\begin{array}{l}\text { - Managerial judgments can } \\
\text { be difficult, in particular } \\
\text { when weighting criteria }\end{array}$ \\
\hline
\end{tabular}

Table 1 - Various Resource Allocation Frameworks for Marketing Decisions 
Despite the availability of an array of different methodologies to set marketing priorities and allocate resources accordingly, several impediments hindering effective marketing resource allocation remain.

\section{Impediments Hindering Effective Marketing Resource Allocation}

In the following section, we use the analytical, behavioural and organisational marketing planning dimensions of Piercy and Morgan (1990) to classify current impediments to the effective setting of strategic marketing priorities.

\section{Analytical Impediments}

Analytical impediments refer to the lack of analytical capabilities and structured methods when allocating marketing resources. The most common analytical impediments are short-term thinking and incrementalism.

The focus on quarterly reports, prevalent in many publicly listed companies, can lead to short-term thinking. A lack of strategic analysis when developing tactical resource allocations (Simkin, 2002) as well as an over-emphasising of short-term sales figures rather than market share growth (Webster, 1988; Dibb, 1997) can be the possible consequences. It can lead to investment in 'established', less risky marketing activities at the expense of new ones (Bonoma and Crittenden, 1988) or the investment in too many short-term focused sales promotions at the expense of advertising (Low and Mohr, 1999).

In particular when changing budgets or during annual planning procedures, another common pitfall is 'incrementalism' - changing budgets in a mechanical process only marginally in relation to the status quo (Piercy, 1986; Piercy and Morgan, 1990). In these cases, 'historical precedent' is the basis for marketing budgeting rather than strategic marketing opportunities (Dalrymple and Thorelli, 1984). 


\section{Behavioural Impediments}

Besides these analytical shortcomings, in particular the lack of vertical communication, lack of strategic consensus and lack of commitment to implementation, can be several motivational reasons for ineffective strategic resource allocation in the marketing domain.

Lack of vertical communication across hierarchies in strategy development processes can lead to inferior strategies (Wooldridge and Floyd, 1990), which in turn can result in lower organisational performance (Floyd and Wooldridge, 1997; Noble and Mokwa, 1999). More involvement in marketing strategy development, on the other hand, can lead to an enhanced search for more alternatives and more diverse information (Collier et al., 2004). This accounts in particular for the involvement of middle management (Dutton et al., 1997; Floyd and Wooldridge, 1997; Floyd and Wooldridge, 1992; Wooldridge and Floyd, 1990) and the enabling of dissent rather than consent (Dooley and Fryxell, 1999). Involvement can also lead to the better alignment of groups through shared strategic understanding and a greater commitment to a joint way forward (Phillips and Bana e Costa, 2006).

Insufficient involvement (Wooldridge and Floyd, 1989) or internal communication efforts (Dibb, 1997) can thereby lead to a lack of strategic consensus on marketing priorities (Rapert et al., 2002). In this context, the area of marketing is in particular suitable for the creation of strategic consensus due to its boundary-spanning role (Rapert et al., 2002). Besides this lack of vertical communication, the separation between formulating marketing strategies, for example, through structured annual planning, and implementation can be drivers for a lack of commitment to the implementation of marketing strategies (Bonoma, 1984; Bonoma and Crittenden, 1988; Piercy, 1990; Piercy and Morgan, 1990; Cespedes and Piercy, 1996; Harris, 1996b, 1996a; Noble and Mokwa, 1999; Lane and Clewes, 2000; Thomas, 2002). 


\section{Organisational Impediments}

Finally, organisational impediments - the lack of organisational structures for effective allocation of resources - can hinder effective marketing priority setting.

Viewed from a top-down perspective, organisations tend to distribute resources equally among their departments or organisational units, rather than applying transparent criteria to allocate resources efficiently (Fox et al., 2005). Similar to Hardin's (1968) common's dilemma, the overall result for the organisation can be inefficient, even if every unit is using their resources efficiently. Quick-growing business units, for example, can be short on resources whilst 'cash cows' burn too much money.

Viewed from a bottom-up perspective, another consequence of the organisational department structure can be a 'silo-thinking' when developing and executing marketing strategies (McDonald, 1992; Dibb and Simkin, 2000; Dibb, 2002). Business units, for example, can tend to develop their marketing strategies only with a perspective on their line of products rather than the company as a whole. Marketing departments, on the other hand, fail to communicate 'laterally' with other departments (Simkin, 1996, Dibb and Simkin, 2000). This lack of cross-functional thinking can thereby decrease organisational performance (Krohmer et al., 2002).

The Marketing Strategy Conferencing Approach, as outlined in the next section, addresses some of these impediments. In the following section, we introduce MSC, applied to two cases for the pharmaceutical, Schering Argentina. 


\section{Marketing Strategy Conferencing}

Marketing Strategy Conferencing is an interactive-analytical approach to identify strategic marketing priorities. The objectives when applying the approach are twofold: first, it is designed to give insights into an efficient allocation of marketing-mix related resources through a consistent comparison of different marketing initiatives (analytical side). Second, MSC provides an effective discussion framework to arrive at a strategic consensus on marketing priorities (interactive side).

\section{Multi-criteria Decision Modelling - The Analytical Side}

The analytical side of the approach builds on a multi-criteria decision model. The building blocks of the model are individual marketing activities, such as different loyalty programs, customer service programs or advertising campaigns. Marketeers analyse each activity based on several benefit and risk dimensions as well as on monetary costs. The approach incorporates financial and non-financial benefits, such as the estimated impact of the activity on sales, its impact on market share, the extent to which the activity enhances corporate image or customer satisfaction.

A multi-attribute utility model then serves to collapse these multiple dimensions into a single risk-adjusted benefit value (Keeney and Raiffa, 1976). If the benefit criteria are constructed preference-independently - i.e. if the decision makers can judge the benefit of an activity on one criterion independently of the impact on another criterion - an additive aggregation of the benefit values is feasible. Following the assessments of all activities on all criteria and the weighting of the criteria to each other, the aggregated benefit value for each

marketing activity can be calculated with the standard additive value model $V_{i}=\sum_{j} w_{j} v_{i j}$. 
$\mathrm{v}_{\mathrm{ij}}$ thereby represents the value associated with the consequence of option $\mathrm{i}$ on criterion $\mathrm{j}$, and $\mathrm{w}_{\mathrm{j}}$ represents the weight assigned to criterion $\mathrm{j}$. The total value score for one option can be calculated as the sum of the weighted scores on each of the individual criteria. For a more detailed explanation of the technical details, see Phillips and Bana e Costa (2006).

Cost, benefit and risk criteria then serve to determine a 'marketing value-for-money triangle' for each activity, as outlined in Figure 1. The slope of the triangle indicates the resource efficiency of each activity: the steeper the slope, the better the benefit-cost ratio of a single activity.

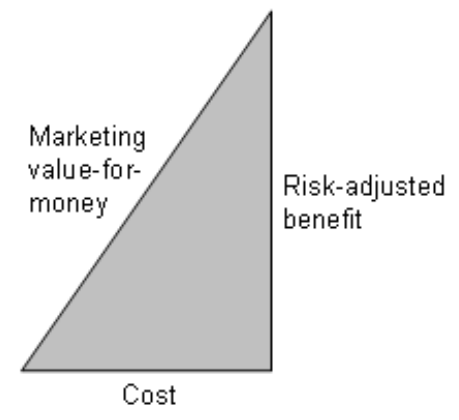

Figure 1 - The Marketing Value-for-money Triangle

The marketing value-for-money of each activity now serves to prioritise strategic marketing activities. Those which lead to a high risk-adjusted benefit with comparatively low costs (steep triangle) should have investment priority over those with lower marketing value-for-money.

\section{Strategy Conferencing - The Interactive Side}

Although priorities might be analytically easy to set, a generation of commitment to related action might prove difficult. Addressing this problem, the decision modelling can facilitate effective vertical and horizontal communication across hierarchies and departments 
in order to create strategic consensus on marketing priorities. An impartial facilitator guides a group of key decision makers through the evaluation process - a process, which Phillips (2006) calls decision conferencing.

Schuman and Rohrbaugh (1991) define decision conferences as 'designed for groups that need to reach consensus about a complex, unstructured problem for which there is no 'formula' or objective solution...' (p. 148/149). The objectives of a decision conference are thereby to create a shared understanding of the issues at stake, to develop a sense of common purpose and to gain commitment to a joint way forward (Phillips, 2006). Usually, the on-the-spot modelling is done within the framework of an intensive two-day meeting (McCartt and Rohrbaugh, 1995) or over a longer time period, which Phillips and Bana e Costa (2006) call 'decision conferencing'.

As the primary purpose of a decision conference is often not to make decisions, but to explore strategic priorities and to contribute to strategic consensus, we call these meetings 'Strategy Conferences'. In the two applications of MSC, outlined below, we carried out the approach within a time frame of several weeks. After a joint kick-off meeting with top-level management, smaller teams started with the collection of expert knowledge and data at the bottom of the hierarchy. This information - incorporated into the decision model - was then checked with the department heads and finally discussed on the next level, the Executive Board. As key stakeholders were engaged in developing the model, the system served to effectively combine the strategic vision of Schering Argentina's top-level management with the operational knowledge of its middle managers. 


\section{Background to the Schering Cases}

The pharmaceutical, Schering has a longstanding history in Argentina. The first subsidiary dates back to 1926 . Focusing mainly on hormonal contraceptives, diagnostic imaging and special therapeutics for multiples sclerosis and oncology, Schering Argentina is above all producing and marketing pharmaceuticals. While originally the market prospects appeared promising in Argentina, over the last few decades, producers and suppliers of generic products have started to challenge Schering in its business segments. The economic crises of 2001/2002 in Argentina further increased the pressure on the company's departments to control costs and maximise the effectiveness of activities.

In 2005, a new CEO took office. Initiating strategic re-thinking within the company, he strove to restore the alignment of local marketing strategy and corporate strategy. In addition, this re-alignment aimed to prevent silo-thinking as the local business units had developed a great sense of autonomy over the years. One reason for this was the nature of the company's products and clients. A lack of cross-unit collaboration was the consequence.

During the research project MARA 2005 (Schaub and Schilling, 2005), we applied MSC for an analysis of Schering's customer service activities across all departments. A follow-up study in 2006, which the Fundación MARA performed, analysed a more diversified marketing portfolio, considering a larger budget. Table 2 provides an overview of these two applications of MSC at Schering Argentina. 


\begin{tabular}{|c|c|c|}
\hline & Schering Case 2005 & Schering Case 2006 \\
\hline Scope & $\begin{array}{l}\text { Prioritisation of selected customer service } \\
\text { activities across all business units }\end{array}$ & $\begin{array}{l}\text { Prioritisation of all marketing activities } \\
\text { within the major business unit }\end{array}$ \\
\hline $\begin{array}{l}\text { Involved participants } \\
\text { (approximation of } \\
\text { overall hours engaged } \\
\text { in meetings) }\end{array}$ & $\begin{array}{l}\text { - CEO }(8 \mathrm{~h}) \\
\text { - three business unit managers }(45 \mathrm{~h}) \\
\text { - eight product managers }(80 \mathrm{~h}) \\
\text { - one medical advisor }(10 \mathrm{~h})\end{array}$ & $\begin{array}{l}\text { - CEO (6 h) } \\
\text { - one business unit manager (42 h) } \\
\text { - five product managers }(90 \mathrm{~h}) \\
\text { - two medical advisors }(16 \mathrm{~h}) \\
\text { - four employees of other areas ( } 32 \mathrm{~h}) \\
\text { - Furthermore, } 40 \text { medical advisors } \\
\text { participated in an online survey to } \\
\text { validate input data }\end{array}$ \\
\hline Time frame & $\begin{array}{l}\text { Following a two-week preparation, four } \\
\text { analysts spent two months on client-site }\end{array}$ & $\begin{array}{l}\text { Following one month of preparation, } \\
\text { three analysts spent three months on } \\
\text { client-site and an additional two weeks } \\
\text { off-site. }\end{array}$ \\
\hline $\begin{array}{l}\text { Number of marketing } \\
\text { options analysed }\end{array}$ & $\begin{array}{l}39 \text { marketing activities in nine customer } \\
\text { service investment areas }\end{array}$ & $\begin{array}{l}65 \text { marketing activities in } 14 \text { marketing } \\
\text { investment areas }\end{array}$ \\
\hline Results & $\begin{array}{l}\text { Potential efficiency increase of } 101 \% \text { in } \\
\text { terms of marketing value-for-money } \\
\text { Strategic insights: significant shift in } \\
\text { customer service resources between } \\
\text { business units would realise efficiency } \\
\text { increases. }\end{array}$ & $\begin{array}{l}\text { Potential efficiency increase of } 118 \% \\
\text { in terms of marketing value-for-money. } \\
\text { Strategic insights: Marketing resource } \\
\text { allocation could be improved by } \\
\text { overcoming previous (historic) } \\
\text { resource commitments }\end{array}$ \\
\hline
\end{tabular}

Table 2 - Overview of Marketing Strategy Conferencing at Schering Argentina 2005 and 2006

\section{The Modelling Process}

For both cases, we constructed marketing activity portfolios, which consisted of a variety of investment areas with several investment options. In 2005, the areas included solely customer service activities. Currently performed service activities, as well as new activities, which we generated interactively with the Schering employees, served as investment options. In order to generate new activities, we asked the clients to imagine options without thinking of budget constraints, i.e. unaffected by associated costs, previous failures, technical or commercial feasibility. Figure 2 displays the portfolio of the Schering 2005 case. The black boxes at the bottom are the labels for the different investment areas, in this case, connected to several product lines. The shaded boxes above refer to the currently 
performed marketing activities; the blank boxes to the possible new marketing activities. Modifications in the nurse service net for one business area or different advertising campaigns, are examples of these options.

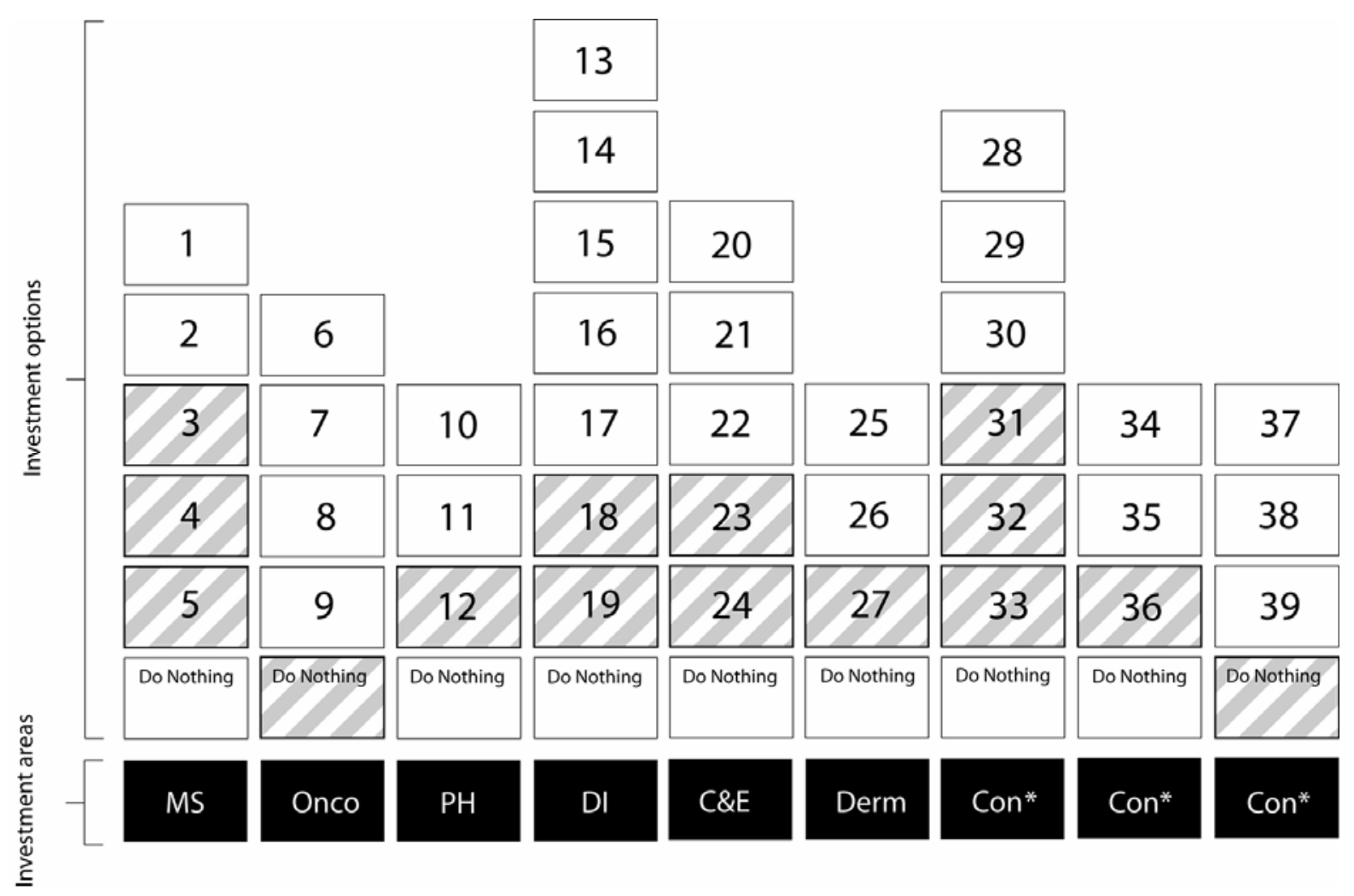

Figure 2 - Marketing Activities Attributed to Investment Areas of the Schering 2005 (* refers to sanitised investment areas)

As the analysis proved useful, in 2006, Schering Argentina decided to repeat the approach within one business unit. In this follow-up case, we focused on the company's largest business unit and increased the scope of the analysis. This analysis included all activities that the business unit directed at the exterior and potential activities that the company could carry out. As a result, the budget in question increased to almost three times the amount we considered in 2005. 
Having created the marketing activity portfolios, in both cases decision makers scored each option on each criterion. In 2005, for example, impact on sales volume, on the company image, and on 'future value' (long-term impact) served, besides monetary costs, as measurement criteria. Following the scoring, the weighting procedure allowed the company to calculate the marketing value-for-money for each activity. Figure 3 shows the creation of the marketing value-for-money triangle. Having carried out all assessments and assigned weights, the model calculated a marketing benefit value for each activity and then prioritised all activities according to their benefit-to-cost ratio.

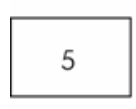

Activity

No. 5

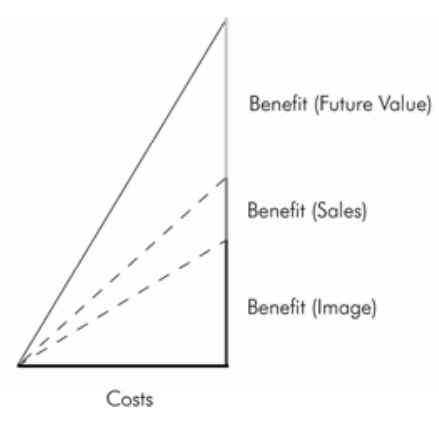

Scoring

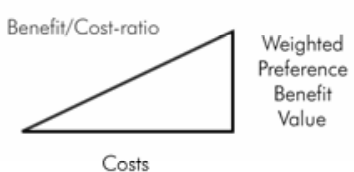

Weighting of Criteria

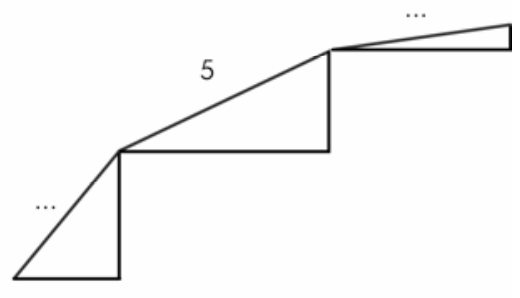

Sorting of B/C Ratios

Figure 3 - The Evaluation Process for a Marketing Activity, leading to an 'Envelope' (Marketing Value-for-money Triangles Stacked According to Decreasing Slope)

After calculating the marketing value-for-money for each activity, we could construct efficient marketing portfolios. Considering, for example, 39 options as analysed in 2005, more than 2.5 million combinations of different activities are feasible. All combinations of activities comprise a benefit and a cost figure. Figure 4 depicts these values as 'envelopes' for the 2005 and 2006 case. The grey-shaded areas contain all benefit-cost combinations of possible portfolios. The black dots on the upper frontier indicate the most efficient of these portfolios. They result for a certain budget in the highest marketing value-for-money. 


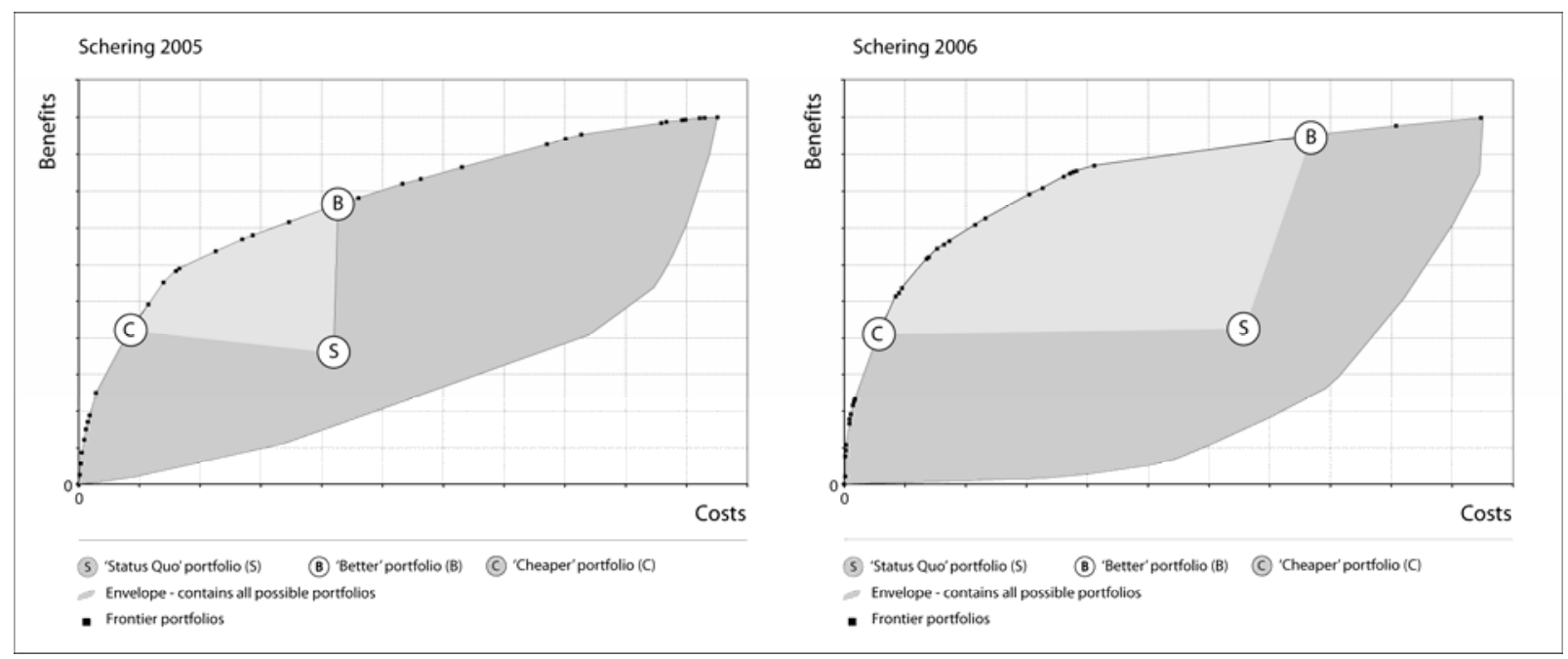

Figure 4 - Portfolio Values for Schering 2005 (left) and Schering 2006 (right). ' $S$ ' indicates the cost and benefit values for the current allocation of resources. ' $B$ ' refers to a better allocation of resources (similar costs, more benefits). ' $C$ ' refers to a cheaper allocation (similar benefits, less costs)

This display serves to identify potential improvements in resource efficiency compared to the status quo of the marketing budget distributions (' $S$ ' in Figure 4). Portfolio suggestions that result in similar or lower costs, but which provide substantially more benefit than the status quo are indicated with a 'B' in Figure 4. The point ' $\mathrm{C}$ ' displays portfolios with a similar benefit level as the status quo, but with substantially reduced costs. In the 2005 case, we identified a 101\% potential efficiency increase, in 2006 an improvement potential of 118\%, compared to the status quo allocation. These efficiency increases can be realised by a reallocation of resources - usually by omitting costly political projects, decreasing spending in some areas, whilst increasing spending in others. As the input data for the model relies on several estimations and assumptions, the potential efficiency increases are approximations. The approach aims not to exactly calculate the total marketing value-for-money for different portfolios, but rather to provide strategic insights into a better allocation of resources.

Whilst the envelopes in Figure 4 represent a top-level view on values of different portfolios, the included or excluded activities cannot be identified. To provide a further 
discussion device, we developed a way to depict the individual efficiency of each marketing activity, as shown in Figure 5. We show each activity with its cost estimate and overall benefit value. Again, the axes reflect benefit and cost values, while the slope of the line connecting the origin and the activity now indicating the efficiency for that activity (Junghänel, 2005). Figure 5 on the left indicates status quo activities with black boxes, whilst displaying possible new activities with white boxes. Activities with the best marketing value-for-money ('High Efficiency' section), result in relative high benefits with lower costs. Using such visualisation, one can easily identify the sources of underperformance of the status quo allocation in 2005. As the status quo activities are distributed across the high, medium, and low efficiency areas, they cannot reach the efficiency level of the 'B' portfolio, as shown in Figure 5 on the right. In this case, the portfolio consists of activities rigidly chosen by moving down along the arrow like a 'wiper' with a fixed point in the origin towards the cost axis. In this display, the wiper stops at the budget constraint that 'separates' included from excluded activities. We did not include any of the activities below the shaded area (right graph) in the portfolio as their efficiency remained too low. 


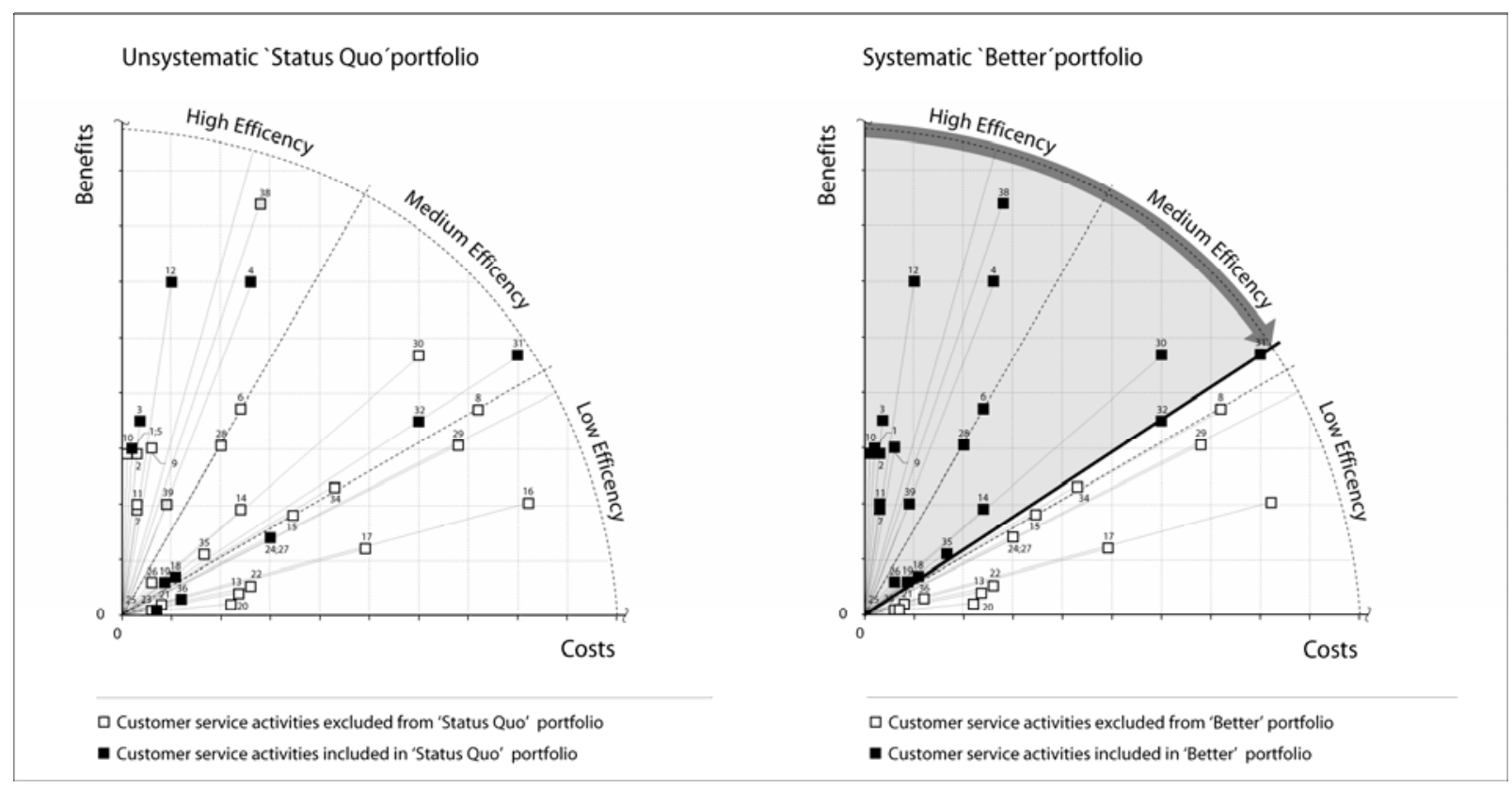

Figure 5 - 'Wiper' Display of the Marketing Value-for-money of the Customer Service Activities from the Schering Case 2005 (adopted from Junghänel, 2005)

Additionally, managers can use this illustration to identify activities whose efficiency ratio lies close to the 'cut-off' line. These activities are rather sensitive to changes in scores and weights or changes in the budget constraint. As such, they qualify for deeper analysis or further validation of input data. It is highly improbable, on the other hand, that a highly efficient activity will drop out of the proposed portfolio due to a slight change in scores or weights. Further analysis of these activities therefore is often not necessary. Phillips (1984) calls these just-enough models 'requisite' as - contrary to other management science models - they focus modelling effort on the most relevant parts of the analysis. A time efficient analysis, appropriate for the decision problem, is the result.

The two applications of Marketing Strategy Conferencing resulted in several insights for Schering Argentina. In 2005, the models gave insights into an efficient re-allocation of marketing resources from one of the business units to new and quick growing businesses. In 2006, results stimulated a critical analysis of historically established, thus little questioned 
activities. Both results led to a significant re-allocation of resources. As the modelling results built on a transparent combination of data and judgment from Schering employees, the recommendation was owned by the managers and thus accepted and implemented. A sustainable strategic consensus on marketing priorities beyond departmental 'silo-thinking' was the consequence.

\section{Conclusion}

In this paper, we have introduced Marketing Strategy Conferencing as a flexible approach to set strategic marketing priorities and allocate resources accordingly. The analytical component of the system - built on a decision model - permits an analysis of the trade-offs between different types of strategic marketing initiatives. The interactive component of the approach - facilitated group meetings with on-the-spot model building and exploration contributes to find strategic consensus on marketing activities and create commitment to action.

We designed the system to overcome some analytical, behavioural and organisational impediments to effective marketing resource allocation. First, the generative approach when creating new marketing activities helps to overcome incrementalism when deciding on marketing priorities. Second, the participatory decision process of Marketing Strategy Conferencing enhances communication across departments and hierarchies, thus contributes to create strategic consensus on marketing priorities. Third, by constructing a portfolio with consistent marketing value-for-money evaluations of each activity, managers can turn a departmental silo-perspective into holistic lateral thinking, enabling them to allocate resources company-wide as efficiently as possible. 
When strategic consensus on marketing priorities is essential, Marketing Strategy Conferencing can be in particular appealing for the allocation of marketing resources. In contrast to the matrix-based approaches, MSC relies on customised rather than generic portfolios. More than twenty years ago, Wind et al (1983) wrote '... given that the conceptually more attractive customised [portfolio] models are more difficult to implement and require greater top management involvement, dominance of standardised portfolio models is likely to continue (p. 89).' Due to the advance of information technology and simple graphical visualisation - essential for top-management applications - the time may be ripe to further enhance customised portfolio models and challenge the dominance of the matrix-based approaches. 


\section{Bibliography}

Alpar, P. (1991). Knowledge-based modelling of marketing managers' problem solving behaviour, International Journal of Research in Marketing 8, 5-16.

Baker, M. J. (2000). Marketing Strategy and Management. London: Macmillan Press.

Blattberg, R. C. and Deighton, J. (1996). Manage Marketing by the Customer Equity Test, Harvard Business Review 74(4), 136-144

Bonoma, T. V. (1984). Making your marketing strategy work, Harvard Business Review 62(2), 69-76.

Bonoma, T. V. and Crittenden, V. L. (1988). Managing Marketing Implementation, Sloan Management Review 29(2), 7-14.

Brown, R. (1991). Making the product portfolio a basis for action Long Range Planning 24(1), 102-110.

Calantone, R. J., Di Benedetto, C. A. and Schmidt, J. B. (1999). Using the analytic hierarchy process in new product screening, Journal of Product Innovation Management 16, 6576.

Cespedes, F. V. and Piercy, N. F. (1996). Implementing Marketing Strategy, Journal of Marketing Management 12(1-3), 135-160.

Changchiena, S. W. and Lin, M.-C. (2005). Design and implementation of a case-based reasoning system for marketing plans, Expert Systems with Applications 28, 43-53.

Chien, T. W., Lin, V. Tan, B. and Lee, W.C. (1999). A neural networks-based approach for strategic planning, Information and Management 35, 357-364.

Chiu, C. (2002). A case-based customer classification approach for direct marketing, Expert Systems with Applications 22(2), 163-168.

Collier, N., Fishwick, F. and Floyd, S. W. (2004). Managerial Involvement and Perceptions of Strategy Process, Long Range Planning 37(1), 67-83. 
Dalrymple, D. J. and Thorelli, H. B. (1984). Sales Force Budgeting, Business Horizons 27(4), 31-36.

Davies, M. A. P. (1994). Using the AHP in Marketing Decision-making, Journal of Marketing Management 10(1-3), 57-73.

Davies, M. A. P. (2001). Adaptive AHP: a review of marketing applications with extensions, European Journal of Marketing 35(7/8), 872-893.

Day, G. S. (1977). Diagnosing the Product Portfolio, Journal of Marketing 41(2), 29-38.

Dhalla, N. K. a. Y., S. (1976). Forget the product life cycle concept!, Harvard Business Review 54(1), 102-113.

Dibb, S. (1997). How marketing planning builds internal networks, Long Range Planning 30(1), 53-63.

Dibb, S. (2002). Marketing Planning Best Practice, Marketing Review 2(4), 1-20.

Dibb, S. and Simkin, L. (2000). Pre-empting implementation barriers: Foundations, processes and actions - the need for internal relationships, Journal of Marketing Management 16(5), 483-503.

Dibb, S., Simkin, L., Pride, W. M. and Ferrell, O. C. (2006). Marketing - Concepts and Strategies. Boston: Houghton Mifflin.

Dooley, R. S. and Fryxell, G. E. (1999). Attaining decision quality and commitment from dissent: The moderating effects of loyalty and competence in strategic decision making team, Academy of Management Journal 42(4), 389-402.

Dutton, J., Ashford, S., Neill, R., Hayes, E. and Wierba, E. (1997). Reading the wind: How middle managers assess the context for selling issues to top managers, Strategic Management Journal 18(5), 407-423.

Dyer, J. S. (1990). Remarks on the Analytic Hierarchy Process, Management Science 36(3), 249-258. 
Eliashberg, J., Swami, S., Weinberg, C. B. and Wierenga, B. (2002). Implementing and Evaluating SilverScreener: A Marketing Management Support System for Movie Exhibitors, Interfaces 31(3), S108-127.

Floyd, S. W. and Wooldridge, B. (1992). Middle management involvement in strategy and its association with strategic type: A research note, Strategic Management Journal 13( Special issue: Strategy Process: Managing Corporate Self-Renewal), 153-167.

Floyd, S. W. and Wooldridge, B. (1997). Middle Management's Strategic Influence and Organizational Performance, Journal of Management Studies 34(3), 465-485.

Fox, C. R., Bardolet, D. and Lieb, D. (2005). Partition dependence in decision analysis, managerial decision making, and consumer choice. In: R. Zwick and A. Rapoport (eds.), Experimental Business Research. Volume III The Netherlands: Dordrecht: Kluwer.

Hardin, G. (1968). The tragedy of the commons, Science 162, 1243-1248.

Harris, L. C. (1996a). The anti-planner's tactics to thwart planning initiation, Journal of Strategic Marketing 4(4), 239-254.

Harris, L. C. (1996b). The impediments to initiating planning, Journal of Strategic Marketing 4(2), 129-142.

Henderson, B. D. (1979). Henderson on Corporate Strategy. Boston: ABT Books.

Hillier, F. S. and Lieberman, G. L. (2005). Introduction to Operations Research. Boston: McGraw Hill.

Junghänel, S. (2005). Marketing budgeting and the across-departmental value trade-off problem: A Marketing Decision Support System based on Multiple-Criteria Decision Analysis. Unpublished manuscript. Technical University Berlin.

Keeney, R. L. and Raiffa, H. (1976). Decisions With Multiple Objectives: Preferences and Value Trade-offs. New York: John Wiley.

Kotler, P. and Keller, K. L. (2006). Marketing Management. Upper Saddle River: Prentice Hall. 
Krohmer, H., Homburg, C. and Workman, J. (2002). Should marketing be cross-functional? Conceptual development and international empirical evidence, Journal of Business Research 55(6), 451-465.

Kuehn, A. A. (1965). Models for the Budgeting of Advertising. In: P. Langhoff (eds.), Models, Measurement and Marketing. Englewood Cliffs: Prentice Hall.

Kuo, R. J. and Xue, K. C. (1998). A decision support system for sales forecasting through fuzzy neural networks with asymmetric fuzzy weights, Decision Support Systems 24, 105-126.

Lane, S. and Clewes, D. (2000). The implementation of marketing planning: a case study in gaining commitment at 3M (UK) Abrasives, Journal of Strategic Marketing 8(3), 225239.

Levy, J. B. and Yoon, E. (1995). Modelling global market entry decision by fuzzy logic with an application to country risk assessment. , European Journal of Operations Research 82(1), 53-78.

Li, S. (2005). A Web-enabled hybrid approach to strategic marketing planning: Group Delphi plus a Web-based expert system Expert Systems with Applications 29(2), 393-400.

Li, S., Kinman, R., Duan, Y. and Edwards, J. (2000). Computer-based support for marketing strategy development: review and questionnaire survey, European Journal of Marketing 34(5/6), 551-576.

Lilien, G. L. and Little, J. D. C. (1976). The Advisor Project: A Study of Industrial Marketing Budgets, Sloan Management Review 17, 17-33.

Lilien, G. L. and Rangaswamy, A. (2003). Marketing Engineering - Computer Assisted Marketing Analysis and Planning. Upper Saddle River, New Jersey: Pearson Eduacation.

Little, J. and Lodish, L. (1969a). A Media Planning Calculus, Operations Research 17, 1-35. 
Little, J. D. C. (1976). Models and Managers: The Concept of A Decision Calculus, Management Science 16(6), B466-B485.

Little, J. D. C. and Lodish, L. M. (1969b). A media planning calculus, Operations Research 17(1), 1-35.

Lodish, L. M. (1971). CALLPLAN: An interactive salesman's call planning system, Management Science 18(4, Part 1), 25-40.

Lodish, L. M. (2001). Building Marketing Models that Make Money, Interfaces 31(3), S45-S55.

Lodish, L. M., Curtis, E., Ness, M. and Simpson, M. K. (1988). Sales force sizing and deployment using a decision calculus model at Syntex Laboratories, Interfaces 18(1), 5-20.

Low, G. S. and Mohr, J. J. (1999). Setting Advertising and Promotion Budgets in Multi-Brand Companies, Journal of Advertising Research 39(1), 67-78.

Mazanec, J. A. (1986). A Decision Support System for Optimizing Advertisting Policy of a National Tourist Office - Model Outline and Case Study, International Journal of Research in Marketing 3, 63-77.

McCartt, A. T. and Rohrbaugh, J. (1995). Managerial Openess to Change and the Introduction of GDSS: Explaining Initial Success and Failure in Decision Conferencing, Organization Science 6(5), 569-583.

McDonald, M. (1992). Ten barriers to marketing planning, Journal of Business and Industrial Marketing 7(1), 5-18.

McDonald, M. and Wilson, H. (1990). State-of-the-Art Developments in Expert Systems and Strategic Marketing Planning, British Journal of Management 1, 159-170.

Mintzberg, H. (1994). The Rise and Fall of Strategic Planning, Harvard Business Review Jan/Feb, 107-114

Montgomery, D. B. and Urban, G. L. (1969). Management Science in Marketing. Englewood Cliffs, N.J.: Prentice-Hall. 
Morrison, A. and Wensley, R. (1991). Boxing up or Boxed in?: A Short History of the Boston Consulting Group Share/Growth Matrix, Journal of Marketing Management 7(2), 105129.

Nguyen, D. (1985). An analysis of optimal advertising under uncertainty, Management Science 31(5), 622-634.

Noble, C. and Mokwa, M. (1999). Implementing marketing strategies: developing and testing managerial theory, Journal of Marketing 63(4), 57-73.

Phillips, L. D. (1984). A Theory of Requisite Decision Models, Acta Psychologica 56, 29-48.

Phillips, L. D. (2006). Decision Conferencing. In: W. Edwards, J. Ralph F. Miles and D. v. Winterfeldt (eds.), Advances in Decision Analysis: Cambridge University Press.

Phillips, L. D. and Bana e Costa, C. (2006). Transparent prioritisation, budgeting and resource allocation with multi-criteria decision analysis and decision conferencing. Annals of Operations Research, in press.

Piercy, N. (1986). Marketin budgeting: a poltical and organisational model. Dover, New Hampshire: Croom Helm Ltd.

Piercy, N. (1990). Marketing Concepts and Actions: Implementing Marketing-led Strategic Change, European Journal of Marketing 24(2), 24-42.

Piercy, N. F. (2002). Market-Led Strategic Change - A Guide to Transform the Process of Going to Market. Oxford: Elsevier Butterworth Heinemann.

Piercy, N. F. and Morgan, N. A. (1990). Organizational Context and Behavioral Problems as Determinants of the Effectiveness of the Strategic Marketing Planning Process, Journal of Marketing Management 6(2), 127-144.

Poh, H. L. (1994). A neural network approach for decision support,, International Journal of Applied Expert Systems 2(3), 196-216. 
Rapert, M., Velliquette, A. and Garretson, J. (2002). The strategic implementation process Evoking strategic consensus through communication, Journal of Business Research 55(4), 301-310.

Reinartz, W., Thomas, J. and Kumar, V. (2005). Balancing Acquisition and Retention Resources to Maximize Customer Profitability, Journal of Marketing 69(1), 63-79

Richardson, R. J. (2004). A Marketing Resource Allocation Model, Journal of Business \& Economic Studies 10(1), 43-53.

Rust, R. T., Lemon, K. N. and Zeithaml, V. A. (2004). Return on Marketing: Using Customer Equity to Focus Marketing Strategy, Journal of Marketing 68(1), 109-127.

Saaty, T. L. (1977). A scaling method for priorities in hierarchical structures, Journal of Mathematical Psychology 15, 234-281.

Saaty, T. L. (1980). The Analytic Hierarchy Process. New York: McGraw-Hill.

Schaub, C. and Schilling, M. (2005). Project Report: MARA 2006 - Merging Methodologies (www.projectmara.com). Buenos Aires.

Schuman, S. P. and Rohrbaugh, J. (1991). Decision conferencing for systems planning, Information and Management 21(3), 147-159.

Simkin, L. (1996). People and Processes in Marketing Planning: The Benefits of Controlling Implementation, Journal of Marketing Management 12(5), 375-390.

Simkin, L. (2002). Tackling implementation impediments to marketing planning, Marketing Intelligence \& Planning 20(2), 120-126.

Thomas, J. S., Reinartz, W. and Kumar, V. (2004). Getting the Most out of All Your Customers, Harvard Business Review 82(7/8), 116-123.

Thomas, L. C. (2002). The nature and dynamics of counter-implementation in strategic marketing: a propositional inventory, Journal of Strategic Marketing 10, 189-204.

Urban, G. L. (1970). SPRINTER Mod III: A model for analysis of frequently purchased consumer goods, Operations Research 18(5), 805-854. 
Vargas, L. G. and Saaty, T. L. (1981). Financial and intangible factors in fleet lease or buy decision, Industrial Marketing Management 10, 1-10.

Venkatesan, R. and Kumar, V. (2004). A Customer Lifetime Value Framework for Customer Selection and Resource Allocation Strategy, Journal of Marketing 68(4), 106-125.

Webster, F. E. (1988). Rediscovering the Marketing Concept, Business Horizons 31(MayJune), 29-39.

Wensley, R. (1981). Strategic Marketing: Betas, Boxes, or Basics, Journal of Marketing 45(3), 173-182.

Wind, Y. and Mahajan, V. (1981). Designing product and business portfolios, Harvard Business Review 59(1), 155-165.

Wind, Y., Mahajan, V. and Swire, D. J. (1983). An empirical comparison of standardized portfolio models, Journal of Marketing 47(2), 89-99.

Wind, Y. and Saaty, T. L. (1980). Marketing Applications of the Analytic Hierarchy Process. , Management Science 26(7), 641-658.

Wooldridge, B. and Floyd, S. (1989). Strategic process effects on consensus.

Wooldridge, B. and Floyd, S. W. (1990). The strategy process, middle management involvement, and organizational performance, Strategic Management Journal 11(3), 231-241. 